DOI: https://doi.org/10.31933/dijms.v2i1 Received: 9 July 2020, Revised: 18 August 2020, Publish: 24 September 2020

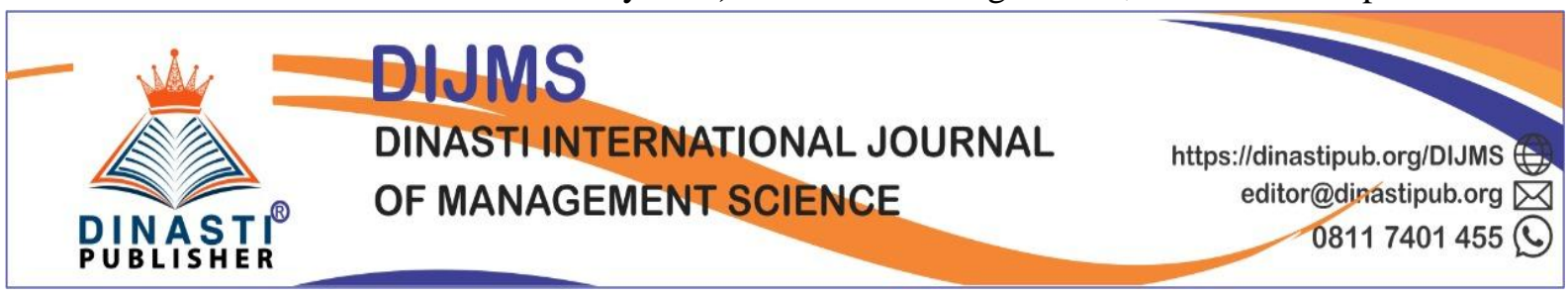

\title{
AUTHENTIC HAPPINESS AS A MEDIATOR OF LEARNING ORGANIZATION AND AUTHENTIC PERSONAL BRANDING ON WORK ACHIEVEMENT
}

\author{
Indira Shanti ${ }^{1}$, Antonius Dieben Robinson Manurung ${ }^{2}$ \\ 1) Magister Management, Mercu Buana,University, Jakarta, Indonesia, shanti indira@yahoo.com \\ 2) Magister Management, Mercu Buana,University, Jakarta, Indonesia, antonius.manurung@mercubuana.ac.id
}

\section{Corresponding Author: First Author}

\begin{abstract}
This study aims to analyze the effect of learning organizations and authentic personal branding on work achievement with authentic happiness as a mediator. Considering work achievement must be used as a goal to motivate employees in order to prepare themselves to enter the era of society 5.0. Data analysis techniques were carried out using structural equation model. The results of this study indicate that; (1) there is a positive and significant influence on authentic happiness on work achievement; (2) there is a positive and significant influence of learning organizations on authentic happiness; (3) there is a positive and significant influence on authentic personal branding on authentic happiness; (4) there is a positive and significant influence of learning organizations on work achievement with authentic happiness as a mediator; and (5) there is a positive and significant influence on authentic personal branding on work achievement with authentic happiness as a mediator.
\end{abstract}

Keywords: learning organization, authentic personal branding, authentic happiness, work achievement

\section{INTRODUCTION}

Society 5.0 is a development of the concept industrial revolution 4.0, emphasizing the element of human capital as central (human centered) and is considered a more humanist concept because even though it is based on technology, it still focuses on humans as the center. The latest concept which was first adopted by the Japanese state is basically a renewal and development of the concept of the industrial revolution 4.0 which is considered to potentially weaken the role of humans as subjects.

The concept of society 5.0 reminds internal and external stakeholders, that when running management, an organization must be able to apply new wisdom with the aim that it can increasingly provide benefits for life, especially relating to human values. This will happen if every manager of the organization or management realizes that the organization that is managed must be able to benefit the lives of the community at large, for the benefit of 
the community, and be increasingly able to improve the lives of the community, both morally and materially (Julitriarsa, 2019).

The concept of society 5.0 is expected to help people transform to live happier and more meaningful lives. The purpose of the concept of society 5.0 is to realize human development, where the individuals in it can enjoy a full life, in the form of positive activities safely and comfortably. The accelerated human resource development program that is determined certainly cannot be separated from the contribution of the performance of StateOwned Enterprises (SOEs) as a strategic business entity that sustains the speed of the country's economy and industry. Therefore, SOEs must be able to show good performance by producing corporate work performance. Achievement of work performance must be used as a goal to motivate employees in order to prepare themselves to enter the era of society 5.0.

The human centered concept of society 5.0 becomes the foundation for the airline company PT Garuda Indonesia as one of the international-scale State-Owned Enterprises (SOEs), to focus more on developing human capital in it and synergizing with the advancement of existing technology.

PT Garuda Indonesia has succeeded in maintaining the award of "The World's Best Cabin Crew" for five consecutive years since 2014, this is a phenomenon that proves the importance of the role of human capital in the organization to create and realize value innovations that have an impact on organizational development (Manurung, 2015). The achievement of PT Garuda Indonesia performance is clear evidence of the ongoing commitment and hard work of all employees, especially the cabin crew who have presented the best flight service "Garuda Indonesia Experience" to all service users.

This award is also a challenge in the future to continue to provide services with the best Indonesian hospitality to the world. Unfortunately, the award of "The World's Best Cabin Crew" cannot be won for the sixth time although maintaining the proud achievement for the sixth time should not be very difficult because providing world-class best service, for cabin crew of PT Garuda Indonesia has become a habit and a work culture.

One form of company support to optimize employee performance is to pay attention to psychological aspects, one of which is authentic happiness. The basic concept of authentic happiness is to identify the strength of self in an effort to carry out work to be more meaningful. This becomes very important, considering the output of the identification process will produce positive energy in the form of motivation to carve out better work performance. Happiness can increase the positive potential of each individual that is influenced by positive institutional aspects of the environment that encourage individuals to be better, responsible, polite, tolerance, moderate, loving, caring and have a high work ethic (Seligman, 2013).

Based on the above explanation, researchers assume and draw pre-conclusions that there is a decrease in management support for the Flight Service Managers (FSM) of PT Garuda Indonesia to maintain the award of "The World's Best Cabin Crew" which is a proud achievement. This interesting fact encourages researchers to conduct research related to the decline in cabin crew performance. Obtained from the results of the pre-research, that there are antecedents that influence the work achievement, including authentic happiness, learning organization, and authentic personal branding. These three antecedents make important 
contributions for FSM to always be able to become role models for cabin crew as a whole to be able to compete in improving service quality and work achievement, as individuals and work teams.

Based on the background of researchers' expectations for achieving desired work achievement with the formation of learning organizations as external factors and authentic personal branding as internal support from each individual, as well as authentic happiness that is maintained, the researcher tries to express thoughts based on the results of several related studies, theories, and reality exists.

Considering the background exposure, it can be identified problems related to authentic happiness as a mediator of learning organizations and authentic personal branding on the work achievement of FSM at PT Garuda Indonesia as follows; (1) the FSM's work achievement is unsatisfactory, this is due to the lack of organizational attention in the application of policies as a system that underlies the concept of the best service to be provided to customers; (2) organizational support is not yet optimal in achieving authentic happiness for FSM as the basis for creating individual work achievement to support corporate performance; (3) the lack of awareness of FSM on the importance of forming learning organizations in the context of creating individual learners and understanding their functions and roles at work; (4) disharmony of authentic personal branding causes FSM to be less optimal in developing a solid work team, and creating the right conditions as a real learning organization.

Based on the framework of thought, the theoretical model of the relationship between variables and the description of previous research as a basis for thinking, the hypotheses proposed in this study are:

Hypothesis 1: there is a positive and significant influence on authentic happiness to work achievement.

Hypothesis 2: there is a positive and significant effect of learning organization on authentic happiness.

Hypothesis 3: there is a positive and significant influence on authentic personal branding on authentic happiness.

Hypothesis 4: there is a positive and significant influence of organizational learning on work achievement with authentic happiness as a mediator.

Hypothesis 5: there is a positive and significant influence on authentic personal branding on work achievement with authentic happiness as a mediator.

\section{LITERATURE REVIEW}

\section{Work Achievement}

The definition of work achievement is a work achieved by a person carrying out the tasks assigned to him based on skill, experience, sincerity and time (Hasibuan, 2012). Individual or employee work achievement is very important for the success of an organization, because humans as one of the factors of production which is the basis or driving force of other factors must be summarized into a single unit in carrying out the production process in the organization in the most effective and efficient so that it can generate profits. 
Munandar (2010) defines work achievement as the interaction of individual personality traits brought into the work organization system, work behavior that is the result of interactions between personality and work environment that takes place during work, and individual work achievements or outputs.

Meanwhile, Manurung (2015) stated that work achievement is basically multidimensional in which there is no single criterion that is able to describe the individual work achievement in the organization as a whole, precise and complete, then suggests 3 aspects that affect employee work achievement, namely: (1) trait aspects including personality, appearance, character, mentality and social relations; (2) behavioral aspects including the application of knowledge about work and organization, cooperation, initiatives, responsibilities, work spirit, and discipline; and (3) managerial aspects including the decision making, coaching and individual development, communication, planning, and work organization.

\section{Authentic Happiness}

Seligman, 2013 stated that authentic happiness is the result of the process of identifying the most fundamental forces and using these strengths in work, romance, and parenting, which is more than just a series of pleasant moments, involving the power of individuals to realize prosperity and goodness.

The authentic happiness theory from Seligman (2013) explains the series of authentic happiness that comes from (1) positive emotions, (2) attachment, and (3) meaningfulness. Although these three things can be achieved separately, they can contribute positively to happiness. Authentic happiness is achieved if the individual lives a meaningful life where the unique virtues of each individual have been holistically empowered.

Virtues explains the main good that is unique with the intent and purpose of everything. Authentic happiness is closely related to the concept of strengths which are similar to the nature which is interpreted as a tendency to behave relatively permanently, where the behavior will be raised in a situation or situation. Simply stated, strengths are the various routes/paths to virtues. The most important thing in this approach is that every individual must be able to find several aspects of strengths and implement them in daily life.

Seligman, 2013 states that the six dimensions of authentic happiness that must be fought for and can be obtained, both simultaneously and separately are; (1) virtue of wisdom and knowledge; (2) virtue of virtue of courage; (3) virtue of love and humanity; (4) virtue of justice; (5) virtue of temperance; and (5) virtue of transcendence.

\section{Learning Organization}

Learning organizations are organizations in which individuals develop their capacity continuously to create the desired results, a broad and newly nurtured mindset, collective aspirations are polished, and endless learning to see things together (Senge, 2006). Learning organizations have the ability to recruit the best employees and prevent employees from leaving to look for more attractive opportunities. In a learning organization, leaders continually show with words and actions on their belief that learning is an important process to enhance organizational growth and also the ability to compete (Sarder, 2016). 
Learning organizations are organizations that powerfully, collectively, and continuously enhance mutual success by gathering, organizing, and using knowledge. Learning organizations also empower human resources in and around them, and utilize technology optimally in order to increase productivity and learning (Marquardt, 2018).

Furthermore, Marquardt (2018) asserted that the ability of organizations to adapt to their environment is determined by the existence of human resources (HR) and organizational climate. Organizations will adapt quickly HR division is sensitive and adaptive to the changes outside the organization, able to learn quickly, and the organization creates an environment that supports the learning process.

The five disciplines of Senge (2006) are stated to be able to build an organization into a learning organization, namely; (1) system thinking (system thinking); (2) personal mastery (personal mastery); (3) mental models (mental models); (3) shared vision (shared vision); and (5) team learning. The five disciplines of Senge (2006) need to be integrated in their entirety, developed, lived by every individual in the organization, and manifested in daily behavior. The five dimensions of learning organizations must be present together in an organization to improve the quality of human resource development, accelerate the learning process of the organization and improve its ability to adapt to changes and anticipate changes in the future.

\section{Authentic Personal Branding}

Rampersad (2009) stated that each individual has a personal brand that can help to grow actively and give themselves the characteristics of being a special professional, but some others are unaware and do not manage it strategically, consistently and effectively. Further, stated that building authentic personal branding is an evolutionary and organic journey and process, which starts from determining authentic personal identity based on dreams, vision, mission, philosophy of life, values, main role, identity, knowledge, and caring self.

Authentic personal branding creates the strongest characteristics, attributes, and values that are believed to separate one individual from most individuals, individuals who do ordinary things with extraordinary efforts (willingness to do more). Efforts to align the personal brand with the character and personality of the self, will create a solid foundation to increase trust, credibility, and charisma (Rampersad, 2009)

Efforts to increase authentic personal branding are needed because it has an impact on individual well-being and organizational effectiveness. The focus of increasing authentic personal branding is to humanize people and a better life through work activities, so as to produce a more positive, conducive and meaningful work environment for the development of work quality, which in turn can affect work achievement (Manurung, 2011). Meanwhile, Kaputa (2003) suggests that personal brand is a strong personal identity in relationships with others based on a clear perception of what is in the individual and the added value that makes successful.

Rampersad (2009), eleven dimensions of authentic personal branding, which next, Manurung (2015) modifies the dimensions/criteria of authentic personal branding from Montoya (2005) and Rampersad (2009), into eight criteria, namely authenticity, integrity, 
consistency, specialization), relevant, visibility, persistency, and goodwill. The dimensions/criteria of authority and distinctiveness contain content that is relatively the same as the criteria of specialization. While performance criteria are not used because they are the final result of authentic personal branding implementation, and then included as separate variables. The eight dimensions/criteria are then used by researchers as a measurement tool in this study.

\section{RESEARCH METHODS}

\section{Analysis Techniques}

The analysis technique used in this study is quantitative analysis to provide an overview and answer the problem formulation. Quantitative analysis technique is done by measuring the level of correlation between exogenous variables and endogenous variables. Researchers used a quantitative approach with statistical verification techniques of Structural Equation Modeling (SEM) statistical analysis. The statistical verification analysis method in the study was carried out using the Linear Structural Model (LISREL) software version 8.72 from Joreskog and Sorbom and SPSS 25 to carry out descriptive analysis.

Determination of the research sample by means of non-probability sampling with limitations on criteria; (1) has experience as a cabin crew for a minimum of 10 years; (2) has experience as a Flight Service Manager for at least 3 years; and/or (3) have experience as a cabin crew instructor for at least 1 year. The population is 420 FSM and researchers took a sample of 231 people.

\section{Data Types and Sources}

There are two types of data sources in this study, namely: 1) primary data obtained directly from the company itself by distributing questionnaires to employees who are respondents; 2) secondary data that has been previously obtained or collected by others or can also be data obtained from reading literature, the internet, books and articles relating to the object of research.

\section{Method of Data Collection}

Data collection method used in this study is to use a questionnaire that must be filled out by respondents who will represent each research variable. The scale that the researchers used in this study is a Likert Scale which shows the effectiveness of the variables measured in 5 categories. This scale measures the level of respondents' perceptions of a series of statements that measure learning organization variables, authentic personal branding, authentic happiness, and work achievement.

\section{FINDINGS AND DISCUSSION}

The following is an analysis of the description of the research variables described.

Table 1. Descriptive Statistics

\begin{tabular}{lllll}
\hline & OP & APB & KO & PK \\
\hline Valid & 231 & 231 & 231 & 231 \\
Missing & 0 & 0 & 0 & 0 \\
The mean & 4,264 & 3,966 & 4,223 & 4,236
\end{tabular}


Table 1. Descriptive Statistics

\begin{tabular}{lllll}
\hline & OP & APB & KO & PK \\
\hline Median & 4,286 & 3,974 & 4,174 & 4,188 \\
Mode & 4,000 & 4026 & 4,109 & 4,000 \\
Std. Deviation & 0.444 & 0.468 & 0.442 & 0.459 \\
Variance & 0.198 & 0.219 & 0.196 & 0.211 \\
Minimum & 2,929 & 2,308 & 3,000 & 3,000 \\
Maximum & 5,000 & 5,000 & 5,000 & 5,000 \\
\hline
\end{tabular}

a More than one mode exists, only the first is reported

Source: SPSS Data Process Results

Based on the table above it can be seen that the average score for the research variable is 4,172 from a scale of 1 to 5 . This illustrates that most respondents stated that the research variables were in the appropriate range, a score of 4.264 for the variable learning organization, score 3,966 for the authentic personal branding variable, score 4,223 for the authentic happiness variable, and score 4,236 for the work achievement variable. Thus, the research variables are in the appropriate category.

The process of testing authentic happiness as a mediator of personal branding and learning organization on work achievement is used goodness of fit. From the results of the analysis obtained the following results.

Table 2. Goodness of Fit

\begin{tabular}{|c|c|c|c|}
\hline Fit Index & Score & Fit Criteria & Information \\
\hline RMSEA & 0.00 & $\leq 0.08$ & fit \\
\hline NFI & 0.99 & $\geq 0.9$ & fit \\
\hline NNFI & 1.00 & $\geq 0.9$ & fit \\
\hline CFI & 1.00 & $\geq 0.9$ & fit \\
\hline IFI & 1.00 & $\geq 0.9$ & fit \\
\hline RFI & 0.99 & $\geq 0.9$ & fit \\
\hline
\end{tabular}

\section{Source: LISREL Data Processing Results 8.72}

Thus, it can be concluded that the model for authentic happiness as a mediator of the learning organization and authentic personal branding on work achievement fit with empirical data.

Based on the LISREL output, the results of the hypothesis test are described as follows.

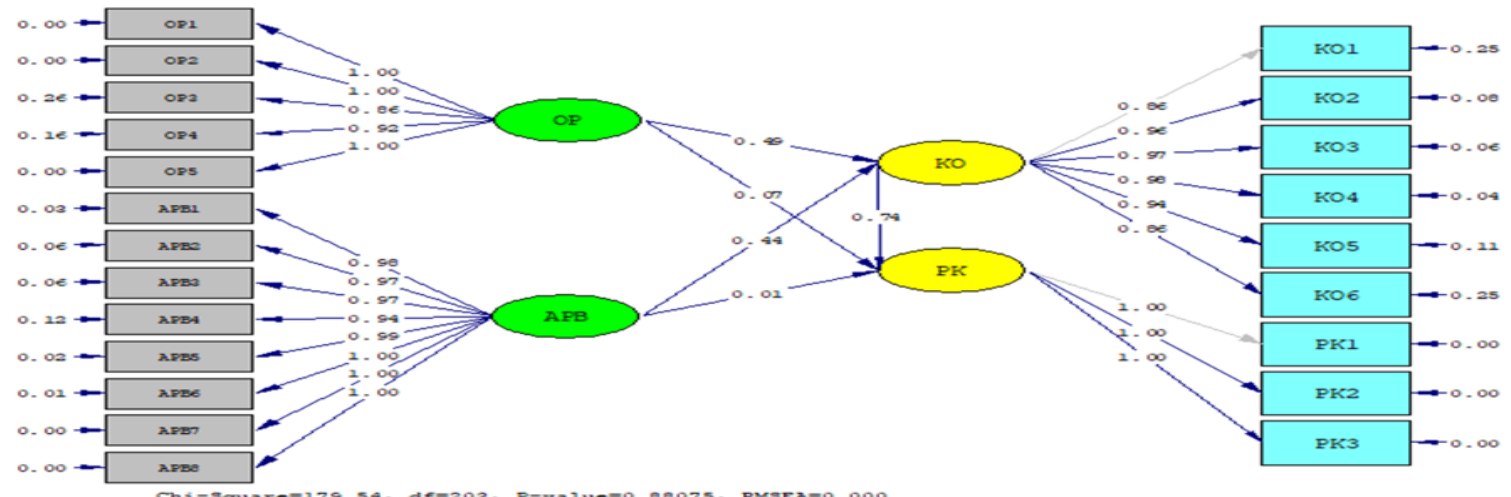

Picture 1. Hybrid Model

Source: LISREL Data Processing Results 8.72 


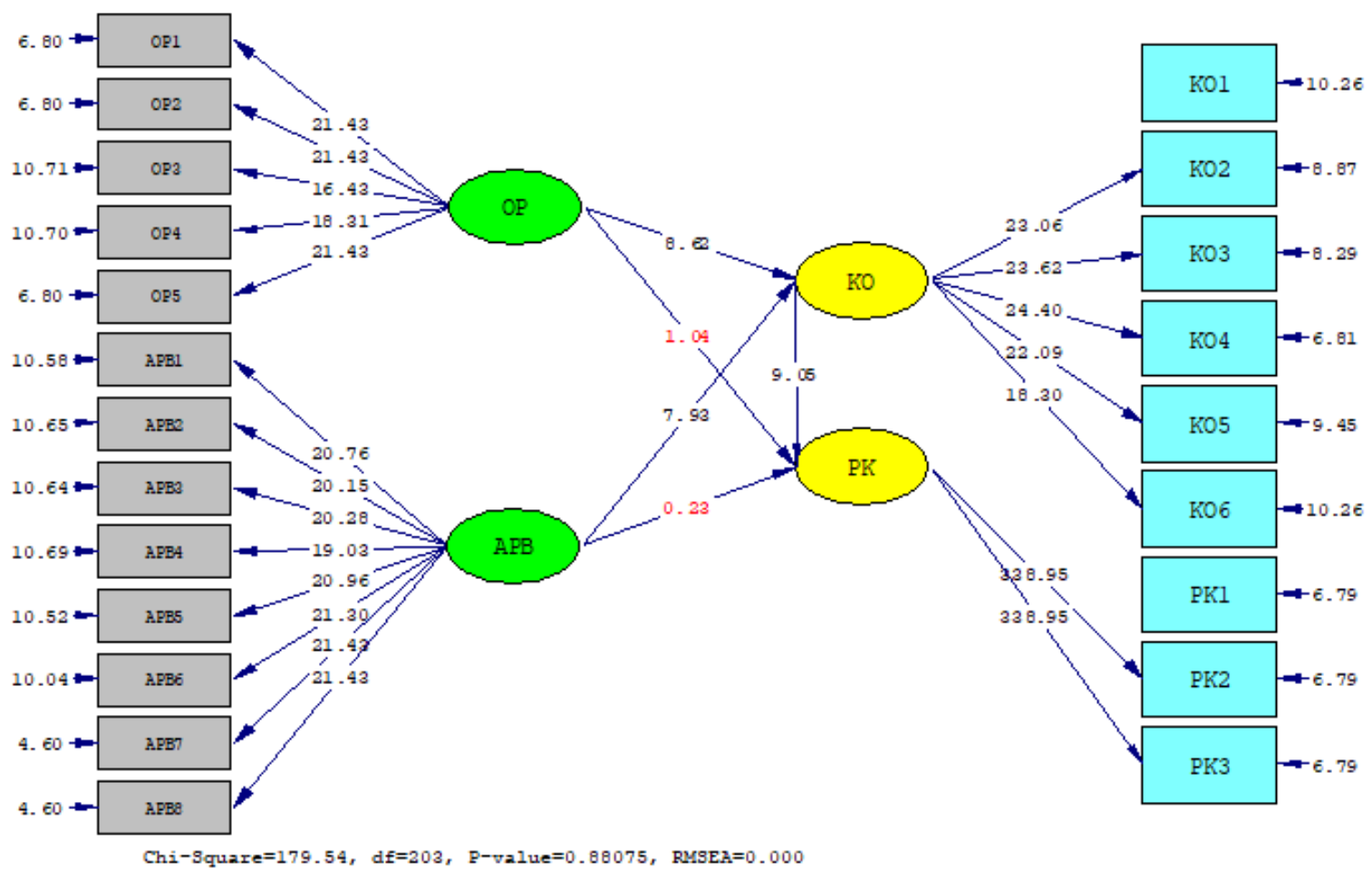

\section{Picture 2. T-Value}

Source: LISREL Data Processing Results 8.72

Analysis for hypothesis 4 and 5 will be presented in the following table of total effect, indirect effect, and direct effect.

Table 3. Total Effect, Indirect Effect, and Direct Effect

\begin{tabular}{cccc}
\hline & Total Effect & Indirect Effect & Direct Effect \\
\hline $\mathbf{O P} \rightarrow$ PK & $0.43^{*}$ & $0.36^{*}$ & 0.07 \\
\hline $\mathbf{A P B} \rightarrow$ PK & $0.34^{*}$ & $0.32^{*}$ & 0.01
\end{tabular}

\section{Source: LISREL Data Processing Results 8.72}

Based on Figure 1 and Table 3, it can be explained that the learning organization variable directly contributes to work achievement by $7 \%$, while the contribution given goes through the authentic happiness variable by $36 \%$. It can be interpreted that the learning organization has a strong influence on work achievement with authentic happiness as a mediator.

The authentic personal branding variable directly contributes to work achievement by $1 \%$, while the contribution given goes through the authentic happiness variable is $32 \%$. Thus, it can be interpreted that authentic personal branding has a strong influence on work achievement with authentic happiness as a mediator.

\section{1) Effect of Authentic Happiness on Work Achievement}

There is a significant influence of authentic happiness variables on work achievement. This can be seen from the analysis results obtained $\beta=0.81$ with $t=14.78$ where $t \geq 1.96$, thus the $\beta$ value is significant, it can be interpreted that authentic happiness has a positive and 
significant effect on the work achievement of FSM PT Garuda Indonesia. The better authentic happiness among FSM in PT Garuda Indonesia, the better achievement will be. The results of data analysis show that authentic happiness has an effect of $81 \%$ on work achievement with the greatest reflection value coming from the third dimension, love and humanity, also from the fourth dimension, namely a sense of justice.

Love, kindness, and friendliness are indicators of the third dimension of the authentic happiness variable. These indicators are very important things to consider in an effort to get authentic happiness of the Flight Service Manager of PT Garuda Indonesia in order to make a positive contribution to the organization. The fourth dimension is sense of justice, with indicators; teamwork, fairness, and leadership are also the dimensions that make the greatest contribution in the authentic happiness variable that affects work achievement. Fairness becomes very important in relation to developing company strategies and producing effective management. A comfortable work atmosphere, positive emotions, and positive synergy will be created if employees feel treated fairly which has an impact on work achievement.

The ability of cabin crew to provide the best service for customers of PT Garuda Indonesia has been proven by the acquisition of the award "The World's Best Cabin Crew" for five consecutive years starting from 2014. This is certainly not inseparable from the organization's capabilities and resources people who support the creation of a comfortable work environment and provide a sense of happiness that encourages employees to achieve and maintain the best performance. The results of this study are in line with Ghaye (in Feldmann, 2017) who stated that positive emotions produce creative actions, ideas, and social relationships that can increase individual resources both physically, cognitively, psychologically, and socially.

\section{2) Effects of Learning Organizations on Authentic Happiness}

There is a significant influence of organizational learning variables on authentic happiness. This can be seen from the results of the analysis obtained values $\gamma=0.79$ with $\mathrm{t}=12.46$ where $\mathrm{t} \geq 1.96$, thus the value $\gamma$ significant, it can be interpreted that the learning organization has a positive and significant effect on the authentic happiness of the FSM. The better the understanding and application of the learning organization among FSM of PT Garuda Indonesia, the authentic happiness will also increase. The results of data analysis show that learning organizations have an effect of $79 \%$ on authentic happiness with the greatest value of reflection from the dimensions of system thinking, personal mastery, and team learning.

The role and function of PT Garuda Indonesia's FSM in every flight is very closely related to the concept of system thinking because all decisions made relating to safety, security, and service aspects to customers must be the ideal decision with consider the smallest risk that the company will face in terms of cost value by not compromising established service standards. The considerations underlying a decision are also inseparable from organizational regulations and, furthermore, government regulations, because PT Garuda Indonesia as an international standard company, it must comply with existing international aviation regulations. 
The dynamics of the problems that arise in each flight are also very closely related to the concept of personal mastery because the problems that arise in each flight have their own uniqueness and are never the same. This requires the ability of the FSM to have expertise in assessing a problem, giving an appropriate reaction, and determining the ideal action or action. Team learning must be applied in every work activity because the success of a flight is the success of a team that works in achieving the targets set. An FSM must also understand the concepts of leadership and followership, open up to get corrections from subordinates, and cultivate learning continuously to achieve better performance.

The concept of learning organization is closely related to the policy and knowledge dimension of the authentic concept of happiness where the indicators that represent this dimension are; creativity, curiosity, open-mindedness, love of learning, and perspective. This reinforces that learning organizations are things that need to be considered in an effort to increase authentic happiness of the FSM PT Garuda Indonesia.

\section{3) Effect of Authentic Personal Branding on Authentic Happiness}

There is a significant influence of authentic personal branding variables on authentic happiness. This can be seen from the results of the analysis obtained values $\gamma=0.77$ with $\mathrm{t}=12.17$ where $\mathrm{t} \geq 1.96$, thus the value $\gamma$ significant. The better the understanding and application of authentic personal branding among FSM PT Garuda Indonesia, the authentic happiness will also increase. The results of data analysis show that authentic personal branding has an effect of $77 \%$ on authentic happiness.

The concept of a full-service airline is an important thing offered by PT Garuda Indonesia and cabin crew in this case is demanded to be a brand ambassador to introduce Indonesian hospitality, especially cabin crew of PT Garuda Indonesia to the world and take the organization to the competitive arena of the international aviation industry. The role of FSM as a cabin crew leader in providing services is very important to be able to always ensure that the services provided are in accordance with established standards.

FSM as a role model for its subordinates must also realize and manage personal brands effectively and consistently in order to maintain the uniqueness and authenticity that are in line with the brand of the organization. It is the duty and responsibility of each individual to build, implement, maintain, and cultivate personal brand for the good of oneself, loved ones, and for the organization (Rampersad, 2009).

Developments in the service industry, especially airlines, have shifted the perspective of the organization, as an external factor, which has paid more attention to the happiness of its employees in an effort to strengthen engagement between organizations and employees. It is undeniable that happy employees will be more motivated to be more creative and produce better achievement. While the internal factors are the efforts of each individual to apply the model of authentic personal branding for the attainment of harmony of heart, mind, and actions in order to achieve authentic happiness. 


\section{4) The Effect of Learning Organizations on Work Achievement with Authentic Happiness as a Mediator}

Learning organizations directly contributed to work achievement by only $7 \%$ with a significance level of 1.04 , while contributions made through authentic happiness were $36 \%$ with $\mathrm{t} \geq 1.96$. This indicates that authentic happiness mediates fully the influence of learning organizations on work achievement. If the authentic happiness of FSM in PT Garuda Indonesia is not heeded, then the implementation of the learning organization will not be maximized on work achievement. The quality of human resources greatly influences the development of an organization, for that organization has the responsibility to support efforts to civilize organizational learning that is carried out continuously in order to prepare flexible and adaptive human resources to the dynamics of global industrial development.

Competition in the international aviation industry requires creative ideas as an organizational strategy to be able to survive and develop. Creativity will emerge from individuals with high levels of authentic happiness, where this is reflected in indicators of the dimensions of wisdom and knowledge that provide support for the role and function of FSM in flight as a responsible person and decision maker in aspects of service and authentic happiness achievement that underlies the implementation process of the dimensions of the learning organization in an effort to improve work achievement. Thus, it can be interpreted that the learning organization has a strong influence on work achievement with authentic happiness as a mediator.

\section{5) The Effect of Authentic Personal Branding on Work Performance with Authentic} Happiness as a Mediator

Authentic personal branding directly contributing to work achievement is only $1 \%$ with a significance level of 0.23 , while the contribution given through authentic happiness is $32 \%$ with $\mathrm{t} \geq 1.96$. This indicates that authentic happiness mediates fully the influence of authentic personal branding on work achievement. If the authentic happiness of the FSM PT Garuda Indonesia is not heeded, then the understanding and implementation of authentic personal branding will not be maximized and will not have a significant positive impact on work achievement.

The cabin crew profession in the aviation industry plays an important role, because in every work activity, cabin crew must be able to fulfill the flight safety, flight security and service aspects. FSM as the leader of the cabin crew in each flight as well as decision makers on problems that often arise, must be able to determine the ideal decision where the three concepts above are considered continuously.

Understanding the concept of authentic personal branding is very important for the FSM, because leaders who have authenticity, integrity, consistency, specialization, relevance, visibility, persistence, and goodwill will affect work achievement as reflected through indicators of the nature, behavioral and managerial aspects. The implementation of authentic personal branding in work and personal life is assumed to affect work achievement (Manurung, 2015). 


\section{CONCLUSION AND SUGGESTION}

After testing the research hypothesis with Structural Equation Modeling data analysis techniques, it can be concluded as follows; (1) authentic happiness has a significant effect on work achievement FSM PT Garuda Indonesia. This shows that the better authentic happiness in the FSM, the work achievement will increase; (2) learning organization has a significant effect towards authentic happiness. This shows that the better level of application in learning organizations can increase authentic happiness among FSM of PT Garuda Indonesia; (3) authentic personal branding has a significant effect on authentic happiness. This shows that the more attention and understanding FSM of PT Garuda Indonesia on authentic personal branding will increase their authentic happiness; (4) authentic happiness mediates fully the influence of learning organizations on work achievement. If the authentic happiness of FSM PT Garuda Indonesia is considered, then the implementation of the learning organization will be maximal and has a significant positive impact on improving work achievement; (5) authentic happiness mediates fully the effect of authentic personal branding on work achievement. If the authentic happiness of the FSM PT Garuda Indonesia is considered, then the understanding and implementation of authentic personal branding will be maximal and will have a significant positive impact on improving work achievement.

As for suggestions related to the conclusions of research are; (1) the need to look for other variables that might have a relationship and their effect on work performance variables; (2) research subjects need to be expanded, not only at the manager level but also at the lower levels, and extended to other international airlines, so that it is more heterogeneous; (3) authentic happiness as a variable that has a significant positive effect directly on work achievement and also fully mediates learning organizations and authentic personal branding to work achievement should be considered and placed as an organizational foundation in creating a good work environment for employees to increase work achievement; (4) authentic happiness as a variable that has a significant positive effect directly on work achievement and also fully mediates learning organizations and authentic personal branding to work achievement should serve as guidelines for real behavior for all employees, especially FSM to overcome the problem of external adaptation and internal integration in the organization; (5) authentic happiness as a variable that has a significant positive effect directly on work achievement and also fully mediates between learning organizations and authentic personal branding to work achievement should be considered and placed as an organizational foundation in creating a good work environment for employees to increase work achievement.

Overall, the conclusions of this study answer the external challenges of PT Garuda Indonesia in the form of economic conditions that have an impact on the aviation industry, as well as internal challenges namely employee capabilities and capacities that still need to be improved. Therefore, the corporate culture transformation strategy through the development of people, process and technology that focuses on improving employee capability and capacity, makes employees comfortable and happy must be continuously improved and also 
prioritizing employees as an asset. Creating a comfortable work atmosphere and happy employees will produce the best service to customers.

Society 5.0 can be interpreted as a concept of society with a new order of life, which is centered on people and based on technology, which can create a more comfortable and sustainable community life. The basic foundation in society 5.0 is the balance in business and economic development with the social environment. In this regard, PT Garuda Indonesia as a State-Owned Enterprise is expected to provide support to all employees as human resources by making employees the most important element and having a central role in all activities that can contribute to various innovations and creativity in organization.

\section{REFERENCE}

Hasibuan, S. P. M. (2012). Manajemen Sumber Daya Manusia. (Rev Ed). Jakarta: PT. Bumi Aksara.

Juliatriarsa, D. (2019). Society 5.0. https://m.bernas.id/66993-society-50.html.

Manurung, A. D. R. (2015). The influence of heroic leadership and learning organization to work achievement with authentic personal branding as mediator. Mediterranean Journal of Social Science, Vol 6, No 5 S5. doi: 10.5901/mjss.2015.v6n5s5p18

Marquardt, M. J. et al. (2002). Building the learning organization: A Systems Approach to Quantum Improvement and Global Success. New York: McGraw-Hill.

Marquardt, M. J. (2018). Optimizing the Power of Action Learning. Nicholas Brealey; 3rd ed. Edition.

Rampersad, H. K (2009). Authentic Personal Branding (Kindle Edition). Information Age Publishing, Inc. www.infoagepub.com.

Sarder, R. (2016). Building an Innovative Learning Organization: A Framework to Build a Smarter Workforce, Adapt to Change, and Drive Growth. DOI:10.1002/9781119235200. https://onlinelibrary.wiley.com/doi/book/10.1002/9781119235200

Seligman, M. E. P. (2013). Authentic happiness. New York. Atria Paperback.

Senge, P.M. (2006). The Fifth Discipline - The Art \& Practice of a Learning Organization, Revised Edition. New York: Doubleday 